\title{
Transplantation
} SPECIAL LECTURES

\section{RESPONSE BY GEORGES MATHÉ}

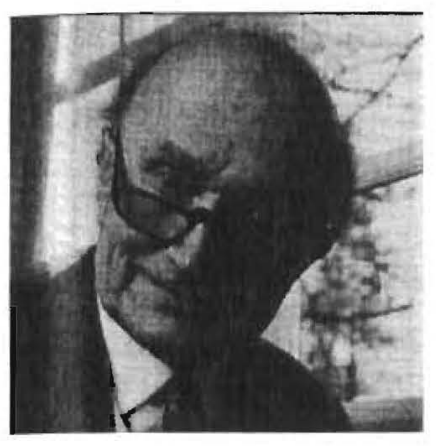

I am very sorry to inform you that Professor Georges Mathe cannot be here. He has been ill for some time with a disabling disease and simply cannot travel. $\mathrm{He}$ asked me to express his heartfelt thanks for the Medawar Prize, which he considers to be the greatest honor of his life. He also sent me a compilation of mementos of his early days in transplantation, with a request that I use it to prepare a response on his behalf. The collection contained a photograph taken in the 1960s of a remarkable assembly of bone marrow transplant pioneers including Dirk van Bekkum, Donnall Thomas, George Santos, and John Trentin. Mathe was in the middle of the group.

Mathe's preoccupation with the treatment of hematolymphopoietic malignancies was symbolized by a photograph of one of his mice, which had been cured of leukemia by total body irradiation and allogeneic bone marrow transplantation in 1958. The animal was one of only seven that survived after allogeneic bone marrow transplantation. Although the mortality was $67 \%$ in these mice, it was $100 \%$ in animals treated with irradiation only or with irradiation plus isogeneic marrow.

The experience with the irradiated Yugoslavian workers treated the next year with allogeneic bone marrow cell infu-

Medawar Prize Laureate, 2002.

Department of Surgery, Thomas Starzl Transplantation Institute, University of Pittsburgh, Pittsburgh, PA.

Address correspondence to: Georges Mathé, 15 rue Buffon 5ieme, 75005 Paris, France.
Thomas E. Starzl, M.D., Ph.D.

sions generated worldwide attention. The possible relevance of this human experience to the treatment of leukemia in humans did not go unnoticed. These Yugoslavian patients were treated before there were practical ways of phenotyping leukocytes. However, the temporary engraftment of the donor bone marrow cells was clearly validated by the presence of donor erythrocytes.

Leukocyte typing had become feasible by the time of Mathé's-and the world's-first successful bone marrow transplantation in 1963, thanks to the discoveries of Jean Dausset, Jon von Rood, Rose Payne, Paul Terasaki, and others. Airtight proof of engraftment in Mathés index case of bone marrow transplantation was provided by analysis of human leukocyte antigens (HLA) and red cell and immunoglobulin phenotypes. Multiple familial donors were used. The transplanted cells that survived and repopulated the recipient were from the donor who had the best HLA compatibility. Tolerance to the donor was demonstrated by skin grafting.

Discouraged by the death of this patient from chronic graftversus-host disease, Mathé began his research on mixed donor leukocyte chimerism in antilymphocyte globulin-pretreated patients. After completing this pathfinding work, Mathé left the field of bone marrow transplantation but not before summarizing his experience in this book written with his associates Jean Louis Amiel and Leon Schwarzenberg.

The memorabilia sent to me by Professor Mathé, which documented these contributions and contained additional personal details, were generated in the 13 years between 1958 and 1971 . The work established dominant themes, both in oncology and transplantation, which have steadily increased in importance in the ensuing third of a century. Professor Mathé deeply regrets not being here to describe this work and to be reunited with old friends. 